\title{
Zinc supplementation could modulate $T$ cell to maintain interleukin-2 level in seropositive contact of leprosy patients
}

\author{
Mohammad Z. Rahfiludin, ${ }^{1}$ Bambang Wirjatmadi, ${ }^{2}$ Indropo Agusni, ${ }^{3}$ Yoes P. Dahlan ${ }^{4}$ \\ ${ }^{1}$ Department of Nutrition and Health, Public Health Faculty, Diponegoro University, Semarang, Indonesia \\ ${ }^{2}$ Department of Nutrition and Health, Public Health Faculty, Airlangga University, Surabaya, Indonesia \\ ${ }^{3}$ Department of Dermatology and Venerology, Medical Faculty, Airlangga University, Surabaya, Indonesia \\ ${ }^{4}$ Department of Parasitology, Medical Faculty, Airlangga University, Surabaya, Indonesia
}

\begin{abstract}
Abstrak
Latar belakang: WHO mencatat jumlah penderita kusta di Indonesia menduduki peringkat ketiga di dunia setelah India dan Brazil. Jumlah penderita kusta baru cenderung meningkat kemungkinan karena yang seropositif kusta telah berubah menjadi manifest klinis. Penelitian ini bertujuan untuk mengetahui pengaruh suplementasi seng terhadap kadar interleukin 2 (IL-2) pada narakontak kusta yang seropositif dengan status seng marjinal.
\end{abstract}

Metode: Dua puluh dua orang berusia 20 - 40 tahun ikut dalam penelitian ini. Kelompok yang disuplementasi seng menerima dosis $40 \mathrm{mg}$ seng/hari selama 3 bulan. Seropositif kusta ditentukan berdasarkan kadar IgM anti Phenolic Glycolipid-1, dan kadar IL-2 pada supernatan kultur sel limfosit diukur dengan metode Elisa.

Hasil: Kadar IL-2 pada kelompok yang menerima seng relatif tidak berubah ( $p=0,721)$, sedangkan pada kelompok plasebo terjadi penurunan bermakna kadar IL-2 $(p=0,025)$ pada akhir penelitian.

Kesimpulan: Terdapat perbedaan bermakna perubahan kadar IL-2 di antara ke dua kelompok $(p=0,037)$. (Med $\mathbf{J}$ Indones 2011; 20:201-4)

\begin{abstract}
Background: WHO classified the number of leprosy cases in Indonesia as number three in the world after India and Brazil. The number of new leprosy patients tends to increase since there is a possibility that seropositive leprosy is turning into manifest leprosy. The aim of this study was to analyze the influence of zinc supplementation on interleukin-2 (IL-2) level of seropositive contact of leprosy patients with marginal zinc deficiency.
\end{abstract}

Methods: Twenty two subjects aged 20-40 years were recruited for this study. The zinc-supplemented group received 40 $\mathrm{mg}$ elemental $\mathrm{Zn} / \mathrm{d}$ orally for 3 months. Seropositive leprosy was determined by examining IgM anti Phenolic Glycolipid-1 level and concentration of IL-2 in lymphocyte cell culture supernatant fluid were measured by Elisa method.

Results: The IL-2 concentration in the subject in the zinc group was relatively not changed $(p=0.721)$, whereas that in placebo group tended to be significantly lower $(\mathrm{p}=0.025)$ at the end of the study.

Conclusion: There was a significant change of IL-2 level between both groups ( $p=0.037$ ). (Med J Indones 2011; 20:201-4)

Key word: IgM anti phenolic glycolipid-1, seropositive leprosy

Leprosy is still a major public health problem in Indonesia as well as in the world. The number of leprosy cases in Indonesia could be classified as number three in the world after India and Brazil..$^{1}$ The number of new leprosy patients tends to increase since there is a possibility that seropositive leprosy is turning into manifest leprosy. Seropositive leprosy is a condition when someone is infected by M. Leprae, however, they have not shown any clinical symptoms. More than half of healthy inhabitants in endemic leprosy area are anti-micro bacterial antibody positive. Therefore seropositive leprosy should get more attention in the effort to eliminate leprosy. Detection of seropositive leprosy subjects can be done by using various methods; one of them is by examining Immunoglobulin M (IgM) anti Phenolic Glycolipid (PGL)-1 level. ${ }^{2}$
Cellular immune response level will determine leprosy spectrum. For leprosy pausibasiler type (PB), the cellular immunity is still good; however for leprosy multibasiler type (MB), the cellular immunity is decreased. ${ }^{3}$ Some researches showed that the immune response was influenced by micro nutrients such as zinc. ${ }^{4}$ Zinc serum level, which may determine leprosy spectrum, plays a role in the cellular immune response. Some research results showed gradual decrease in zinc serum level on the transition of leper type PB to MB. The lowest level is found in MB type. ${ }^{5}$

Zinc plays a role in cytokine production such as interferon (IFN)- $\gamma$, interleukin (IL)-2, and Tumor Necrosis Factor (TNF)- $\alpha$. T-helper 1 (Th1) cytokine products, such as IFN- $\gamma$ and IL- 2 are decreased in zinc 
deficiency. IFN- $\gamma$ and IL-2 production is improved when zinc level is maintained to be sufficient by giving zinc supplement. ${ }^{6}$

Seropositive contacts of leprosy patients have a tendency to change into leprosy multibasiler type (MB). Cellular immunity of leprosy MB is decreased or even reaches anergy, and it turns into humoral immunity (Th2), which makes the patient's condition worse. Therefore, this study aimed to analyze the influence of zinc supplementation on interleukin 2 (IL-2) level of seropositive contact of leprosy patients with marginal zinc deficiency. Zinc supplementation is expected to increase IL-2, and in turn will maintain the function of cellular immunity in seropositive leprosy.

\section{METHODS}

This study was conducted on people who live in the same house or near the leper population in Brondong subdistric, Lamongan regency, East Java, Indonesia in 2010. The amount of the research sample was predetermined, i.e. 22 subjects who were randomly chosen from those who met the inclusion criteria. The ethical clearance for this study was obtained from Research and Public Service Institute, Airlangga University no. 071/PANEC/LPPM/2009.

\section{Inclusion criteria}

The inclusion criteria were individuals of 20 to 40 years old (both male and female) whom were proven to be leprosy serology positive (IgM anti PGL-1 level is $600-1500 \mathrm{unit} / \mathrm{ml}$ ) and had marginal zinc status (zinc plasma level $10.7-13.0 \mu \mathrm{mol} / \mathrm{L}$ ). In addition, they did not clinically show any leprosy symptoms and did not consume anti-leprosy medicine. They also did not have any disease, which might influence their zinc status, did not suffer from tuberculosis and did not consume any anti-tuberculosis drugs; they did not consume any anti-immunosuppressant in the last three months before blood samples were taken; their body mass indexes were more than $18 \mathrm{~kg} / \mathrm{m} 2$ and were willing to join the study by signing an informed consent form.

\section{Zinc supplementation}

Those 22 subjects were randomly assigned in pairs to receive either zinc-supplement (treatment group) or placebo (placebo group). Each day for 3 months, subjects in the treatment group received 1 capsule of zinc sulfate (40 mg elemental zinc), while subjects in the placebo group received placebo capsules in the same manner. The obedience of consuming supplement was monitored by the researchers and local health staff.

\section{Procedures}

Plasma zinc levels were measured by using atomic absorption spectrophotometer in Balai Besar Laboratorium Kesehatan Surabaya. Determination of seropositive leprosy was done by examining IgM anti PGl-1 level by enzyme-linked immunosorbent assay using polyclonal rabbit anti human IgM/HRP secondary antibody $\left(\right.$ Dako $\left.^{\circledR}\right)$. The assay was developed in the Institute Tropical Disease Laboratory, Airlangga University, Surabaya. In addition, daily intake was measured using recall method and food frequency questionnaire, and IL-2 measurements on peripheral blood mononuclear cells in cultures were done.

\section{Peripheral blood mononuclear cell culture and IL2 measurements}

Peripheral blood mononuclear cells $\left(3 \times 10^{-7} \mathrm{~g} / \mu \mathrm{l}\right.$ per well) were stimulated with a mitogen (Dharmendra lepromins) in culture for 2 days in $10 \% \mathrm{CO}_{2}$ at $37{ }^{\circ} \mathrm{C}$. Supernatant was collected from lepromin-stimulated cell culture, and the IL-2 level was measured by using commercial enzyme-linked immunosorbent assay kits (Quantikine ${ }^{\circledR}$ catalog number D2050, R\&D System, Inc Minneapolis, USA) in Pathology laboratory of Dr. Soetomo hospital, Surabaya. Concentrations of IL-2 were expressed as $\mathrm{pg} / \mathrm{mL}$ supernatant.

\section{Data collection and analysis}

Data collected were characteristics of the sample, daily intake, and anti PGL-1 IgM. In addition, data of plasma zinc and IL-2 levels before and after supplementation were also collected. All data were noted and tabulated. Normality of the data was determined by the KolmogorovSmirnov test. Statistical analyses were done using SPSS 16 statistical software, to compare plasma zinc and IL-2 level between treatment and placebo group by independent $t$ test. Further, paired $t$ test was used to compare plasma zinc as well as IL-2 levels of before and after supplementation. Fisher's exact was used to compare the two sexes between groups.

\section{RESULTS}

To know whether someone was leprosy seropositive, a serology test (IgM anti PGL-1) was conducted on 153 subjects who live in the same house with a leprosy patient or near the leper population. The average level of IgM anti PGL-1 was $1047 \mathrm{pg} / \mathrm{mL}( \pm$ 823.6). The examination results showed that 78 subjects $(51 \%)$ were leprosy seropositive on the level of $600-1500$ $\mathrm{pg} / \mathrm{ml}$. Next, zinc plasma examination was done. The average level of zinc plasma on those subjects was 13.9 $\mu \mathrm{mol} / \mathrm{L}( \pm 1.98)$. From the 78 seropositive subjects, 30 
(37.7\%) experienced marginal zinc deficiency (zinc plasma level 10.7 - $13.0 \mu \mathrm{mol} / \mathrm{L})$.

The comparative result showed that there was no significant difference of sex, body mass index and IgM PGL-1 level between both groups (table 1). Further, there was no difference in daily intake between the two groups (Data not shown).

Table 1. Subject characteristics and IgM anti PGL-1 level

\begin{tabular}{|c|c|c|c|}
\hline \multirow[t]{2}{*}{ Variable } & \multicolumn{2}{|c|}{ Groups } & \multirow{2}{*}{$\mathrm{p}$} \\
\hline & Placebo & Zinc & \\
\hline $\operatorname{Sex}(n)$ & & & $1.000^{\mathrm{a}}$ \\
\hline - Male & 3 & 2 & \\
\hline - Female & 8 & 9 & \\
\hline Age (year) & $26( \pm 6.3)^{c}$ & $31( \pm 5.3)^{\mathrm{c}}$ & $0.062^{\mathrm{b}}$ \\
\hline Body Mass Index & $21.3( \pm 2.5)^{\mathrm{c}}$ & $22.1( \pm 2.5)^{\mathrm{c}}$ & $0.468^{\mathrm{b}}$ \\
\hline IgM anti PGL-1 (unit/mL) & $993( \pm 224)^{\mathrm{c}}$ & $968( \pm 209)^{\mathrm{c}}$ & $0.793^{\mathrm{b}}$ \\
\hline
\end{tabular}

$\mathrm{a}=$ Fisher's Exact test, $\mathrm{b}=$ independent $\mathrm{t}$ test, $\mathrm{c}=$ mean $( \pm \mathrm{SD})$

On placebo group, the average of zinc plasma level was relatively the same at the beginning and the end of the study $(p=0.133)$. However, there was a major increase in zinc plasma level on treatment group $(\mathrm{p}=$ 0.001). There was no significant difference between the treatment and placebo group in baseline plasma zinc level $(p=0.823)$ and 3 months after treatment $(p$ $=0.819$ ). However, there was significant difference in the change of zinc plasma level between both groups ( $\mathrm{p}$ $=0.002)$ (Table 2$)$.

Table 2. Average of difference in Zinc plasma level before and after the study

\begin{tabular}{lcccc}
\hline & \multicolumn{3}{c}{ Plasma Zinc $(\mu \mathrm{mol} / \mathrm{l})$} & $\mathrm{p}$ \\
\cline { 2 - 4 } & Before & After & Change & \\
\hline Placebo & $12.3( \pm 0.8)$ & $12.3( \pm 0.7)$ & $0.05( \pm 0.11)$ & $0.133^{\mathrm{a}}$ \\
Zinc & $12.2( \pm 0,8)$ & $12.4( \pm 0.8)$ & $0.21( \pm 0.09)$ & $0.001^{\mathrm{a}}$ \\
$\mathrm{p}$ & $0.823^{\mathrm{b}}$ & $0.819^{\mathrm{b}}$ & $0.002^{\mathrm{b}}$ & \\
\hline
\end{tabular}

$\mathrm{a}=$ paired $\mathrm{t}$ test, $\mathrm{b}=$ independent $\mathrm{t}$ test

On placebo group, IL-2 level after 3 months was significantly lower than baseline $(\mathrm{p}=0.025)$. However, on treatment group, IL-2 level was relatively stable $(\mathrm{p}=$ 0.721 ). There was a significant difference between the treatment and placebo group in IL-2 concentration at baseline $(\mathrm{p}=0.032)$, but after 3 months of treatment there was no significant difference $(p=0.750)$. Conversely, there was significant change of IL-2 level between the two groups $(\mathrm{p}=0.037)$ (Table 3$)$.
Table 3. Average of difference of IL-2 level before and after the study

\begin{tabular}{lcccc}
\hline & \multicolumn{3}{c}{$\mathrm{IL}-2(\mathrm{pg} / \mathrm{ml})$} & \multirow{2}{*}{$\mathrm{p}$} \\
\cline { 2 - 4 } & Before & After & Change & \\
\hline Placebo & $36.1( \pm 19.1)$ & $20.1( \pm 12.5)$ & $-15.1( \pm 19.1)$ & $0.025^{\mathrm{a}}$ \\
Zinc & $21.0( \pm 11.8)$ & $19.4( \pm 11.8)$ & $-0.8( \pm 7.2)$ & $0.721^{\mathrm{a}}$ \\
$\mathrm{p}$ & $0.032^{\mathrm{b}}$ & $0.750^{\mathrm{b}}$ & $0.037^{\mathrm{b}}$ & \\
\hline
\end{tabular}

$\mathrm{a}=$ paired $\mathrm{t}$ test, $\mathrm{b}=$ independent $\mathrm{t}$ test

\section{DISCUSSION}

Screening results showed that $51 \%$ of inhabitants in Brondong sub district, Lamongan regency, East Java, were leprosy seropositive based on IgM anti PGL-1 examination. This finding is higher than that in South Korea that was $12.1 \%$ and in the Philippines that was $13.9 \% .^{7}$ However, this finding is relatively the same compared to that in Semarang, Central Java, namely $53 \% .{ }^{8}$ Indonesia has a higher prevalence of seropositive leprosy; this fact corresponds with the number of leprosy cases in Indonesia that could be classified as number three in the world after India and Brazil. ${ }^{1}$

Zinc supplementation on leprosy seropositive subjects for three months was proven to be able to prevent the decrease in IL -2 level, since zinc can give influence on T-cell signal transduction that started from the proximal (cell membrane) level to the distal level (nucleolus transcription).

On proximal level, this fact can be explained since zinc has an effect on lymphocyte protein tyrosine kinase (Lck). On the next signal transduction, zinc influences protein kinase $\mathrm{C}$ and extracellular-signal regulated kinase (Erk). Zinc is needed for homodimerization and heterodimerization of Lck. Zinc capability on homodimerization and heterodimerization was specific for Lck. This capability was due to cystein residues, which form two intermolecular zinc binding-sites that are unique and are not present in other Scr kinase family members. ${ }^{9}$ Protein kinase $\mathrm{C}$ also causes nuclear factor kappa B (NFkB) to be free from its bond in the cytoplasma and then entered the nucleus. Zinc has an effect on the activation of inhibitor $\mathrm{kB}$ (I $\mathrm{KB}$ ) kinase and the expression of mRNA p105 (prekursor NFkB p50). Then, zinc also influences the phosphorylation and ubiquitination process on I $\mathrm{KB}$, so that it is degraded, and makes it possible to translocate NFKB from cytosol to the nucleus. Next, NFאB connects with DNA and then, IL-2 mRNA transcription process happens. ${ }^{10}$

Zinc can cause phosphorylation of Mek and Erk. Dephosphorylation in vitro to examine the effect of 
zinc toward the phosphorylation of Mek and Erk showed that zinc can protect those two kinases from dephosphorylation. ${ }^{11}$

If the T-cell signal transduction runs well, transcription factors such as nuclear factor of activated $\mathrm{T}$-cells (NFAT), NFאB and activator protein-1 (AP-1) that control IL -2 gene transcription will work well. ${ }^{12}$

Significant decrease of IL-2 level on placebo group can be explained since Mycobacterium leprae is able to destroy T-cell signal transduction, which causes T-cell proliferation decrease. Mycobacterium leprae defects the activities of jun-NH2-terminal kinase (JNK) and ERK. The defected activities of JNK and ERK will cause the decreased activity of AP-1. Moreover, there are also reduced calcium levels, protein kinase $\mathrm{C}$ activity and calcineurin activity. Lower calcium level, activities of protein kinase $\mathrm{C}$ and calcineurin can interfere with the transcription factors of NFAT and NFkB. ${ }^{13}$

Mycobacterium leprae can interfere with host immune response by lowering costimulatory molecules activity of host cell. The expression of B7-1 and CD 28 were significantly decreased in patients with untreated lepromatous leprosy disease. Down regulation of B7-1 and CD 28 in lepromatous leprosy may be responsible for a defective $\mathrm{T}$ cell signaling by the B7-1/CD 28 pathway due to $M$. leprae antigens. ${ }^{14}$

In conclusion, Zinc supplementation could modulate $\mathrm{T}$ cell to maintain IL-2 level production in leprosy seropositive subjects with marginal zinc deficiency.

\section{Acknowledgments}

Our grateful thank to Prof. Shinzo Izumi, MD, PhD, Leprosy Study Group of Tropical Disease Center, Airlangga University, Surabaya, for providing us mitogen Dharmendra lepromins.

\section{REFFERENCES}

1. World Health Organization (WHO). Global leprosy situation. Wkly Epidemiol Res. 2006; 81: 309-16.

2. Izumi S. Subclinical infection by Mycobacterium leprae. Int J Lepr. 1999; 67 (4) (Suppl):S67-71.

3. Scollard DM, Adams LB, Gillis TP, Krahenbuhl JP, Truman RW, Williams DL. The continuing challenges of leprosy. Clin Microbiol Rev. 2006; 19: 338-81.

4. Prasad AS. Zinc: Mechanisms of host defense. J Nutr. 2007; 137: 1345-9.

5. George J, Bathia VN, Balakrishnan S, Ramu G. Serum zinc/ copper ratio in subtypes of leprosy and effect of oral zinc therapy on reactional states. Int J Lepr. 1991; 59: 20-4.

6. Prasad AS, Bao B, Beck FWJ, Sarkar FH. Zinc enhances the expression of interleukin-2 and interleukin-2 receptors in HUT-78 cells by way of NF- $\mathrm{KB}$ activation. J Lab Clin Med. 2002; 140; $272-89$.

7. Cho SN, Kim SH, Cellona RV, Chan GP, Fajardo TT, Walsh GP, et al. Prevalence of IgM antibodies to phenolic glycolipid I among household contacts and controls in Korea and the Philippines. Lepr Rev. 1992; 62: 12-20.

8. Rahfiludin MZ, Kartasurya MI, Purwaningsih E. The different levels of interferron gamma capacity production on several stages of leprosy. Med J Indones. 2007; 16: 224-7.

9. Haase H, Rink L. Functional significance of zinc-related signaling pathways in immune cells. Annu Rev Nutr. 2009; 29: 133-52.

10. Prasad AS. Clinical, immunological, anti-inflammatory and antioxidant roles of zinc. Exp Gerontol. 2008; 43: 370-7.

11. Kaltenberg J, Plum LM, Ober-Blöbaum JL, Hönscheid A, Rink L, Haase H. Zinc signals promote IL-2 - dependent proliferation of T cells. Eur J Immunol. 2010; 40: 1496-1503.

12. Abbas AK, Lichtman AH. Basic immunology functions and disorders of the immune system. third edition. Philadelphia: Saunders Elsevier; 2011.

13. Chattree V, Khanna N, Rao DN. Alterations in T cell signal transduction by $M$. leprae antigens is associated with downregulation of second messengers PKC, calcium, calcineurin, MAPK and various transcription factors in leprosy patients. Mol Immunol. 2007; 44 (8): 2066-77.

14. Agrewala JN, Kumar B, Vohra H. Potential role of B7-1 and CD28 molecules in immunosuppresion in leprosy. Clin Exp Immunol. 1998; 111: 56-63. 